\title{
Rabbit production under intensive system in rural condition
}

\author{
R. Khatun*, M. N. Islam, M.A. Rashid and S. Ahmed \\ Bangladesh Livestock Research Institute, Savar, Dhaka \\ *Corresponding author: rkbaby96@yahoo.com
}

\begin{abstract}
A total 20 (sixteen female and four male) growing rabbits aged 120 days have been distributed at each farmer's level in 5 location of Bangladesh; $F_{1}$ (Dhaka-Pollobi), $F_{2}$ (Savar-Parbotinagor), $F_{3}$ (MaguraBoralidhaho), $\mathrm{F}_{4}$ (Magura-Pannandualli), $\mathrm{F}_{5}$ (Magura-Radhanagor) to know the production response and cost effectiveness under intensive in rural condition. The rabbits were reared in their own arrangement. Age of sexual maturity, age of first kidding, percentage of does kidded, gestation period, litter size, weaning period, breeding ratio were not significantly different $(\mathrm{P}>0.05)$ among the locations. Feed cost per month was Tk. 903, Tk. 732, Tk. 772, Tk. 1221.96 and Tk. 976 for $F_{1}, F_{2}, F_{3}, F_{4}$ and $F_{5}$ respectively for 20 rabbits rearing. Monthly consumption of rabbit meat per family was $4.5 \mathrm{~kg}, 3 \mathrm{~kg}, 2.4 \mathrm{~kg}, 6.0 \mathrm{~kg}$, in $\mathrm{F}_{1}, \mathrm{~F}_{2}, \mathrm{~F}_{3}$, and $\mathrm{F}_{5}$ respectively. Kid mortality ( $0-10$ days) was significantly different $(\mathrm{P}<0.01)$ among the locations and this value was recorded $8.47 \%, 11.11 \%, 12.00 \%, 8.82 \%$ and $13.11 \%$ in $\mathrm{F}_{1}, \mathrm{~F}_{2}, \mathrm{~F}_{3}, \mathrm{~F}_{4}$ and $\mathrm{F}_{5}$ respectively. Farmer earned some money by selling their rabbit which was Tk 10200, Tk7600, Tk8400, Tk12400 and Tk7200 /batch and can earn profit around the 49,564; 39,316; 38,536; 62,336 and 35,688 Tk/year in rearing (7batchs/year) 20 rabbit at in $\mathrm{F}_{1}, \mathrm{~F}_{2}, \mathrm{~F}_{3}, \mathrm{~F}_{4}$ and $\mathrm{F}_{5}$, respectively. Rabbit production could be an important micro-livestock component to produce for meeting up extra demand of the country.
\end{abstract}

(Keywords: Rabbit, intensive, rural area, production performance and cost benefit)

\section{Introduction}

Micro-livestock like rabbit can play a significant role for poverty alleviation among smallholder farming community in Bangladesh. They are found in different districts and almost all of them are mainly reared by the landless and marginal farmers in the rural areas and very few portions of their population are reared by the inhabitant of metropolitan cities. Now a days, many NGO's and other Govt. organizations have taken initiative on rabbits farming as an income generating activity for the destitute women and school going children. Farmers rearing small scale rabbit opined that rabbits farming is obviously profitable enterprise but sometimes marketing problem of rabbit have occurred those who reside in the remote areas. But the farmer resides in the metropolitan cities or town did not face such type of marketing problems. People resides in the metropolitan cities purchased rabbit for meat consumption as well as game animal. Rabbit could be reared in homestead with minimum cost by proper utilization of family labour and homestead feed sources with little or no extra inputs without hampering the other farming activities. It has not been received due attention though it is a source of good quality meat. The meat of rabbit is a rich source of protein, energy, minerals and vitamins and low in fat, sodium and cholesterol. It is also reported that rabbit meat is delicious and higher in protein contents (Jones,1990; Handa et al.1995; Ali and Sukanta,1993; and Sandford,1986). It reaches sexual maturity at the age of 4-5 months, litter size is about 2-7 and gestation period is about 1 month. A female rabbit reproduce 5-7 times in a year (Cheeke, 1986b; Hasanat et al. 2006). Feed cost is negligible because it can directly convert forages into animal protein. The average daily per capita availability of animal and fish protein is only $15.5 \mathrm{~g}$ resulting in an animal to plant protein ratio of 1:3.70 in place of the required amount of $30 \mathrm{~g}$ and a dietary ratio of $1: 1$. Livestock and poultry, at present, contribute 
only $7.1 \mathrm{~g}$ dietary animal protein and it requires almost double production of milk, meat and eggs (Huque, 2009) to support food security.

In order to maximize the food production in Bangladesh, all possible options including rabbit production may be addressed. The climatic conditions, commercial factors, ecological environment, religious points of view, social practices and technological know-how support the rabbit production in Bangladesh (MIDAS, 1992).

In Bangladesh, systematic studies have not yet been done on their production performance, problems and prospects and economic impact as an income generating enterprise. In a locationbased study indicates that rabbit rearing have much impact on poverty reduction under low-input production system. Under above circumstances the present study was designed to know the production response and cost effectiveness of rabbit under intensive system in rural condition.

\section{Material and Method}

Poultry Production Research Division of Bangladesh Livestock Research Institute has been distributed a total 100 New Zealand White $(\mathrm{NzW})$ type growing rabbits aged 120 days at farmer's level at 5 locations of Bangladesh; $F_{1}$ (Dhaka-Pollobi), $F_{2}$ (Savar-Parbotinagor), $F_{3}$ (Magura-Boralidhaho), $\mathrm{F}_{4}$ (Magura-Pannandualli), $\mathrm{F}_{5}$ (Magura- Radhanagor). Eighty female and 20 male rabbits were randomly assigned to five groups, so that each having group sixteen female and four males. The rabbits were reared in intensive system (bamboo made cage rearing) at farmers own arrangement. Record of productive and reproductive parameters of rabbit under intensive system in rural condition were kept during study (about 10 months). The animal was fed concentrate diets contained average $2877 \mathrm{ME} \mathrm{Kcal} / \mathrm{kg}$ and $17.86 \% \mathrm{CP}$ with adlibitum with seasonal vegetable/green grass which was supply by the farmers from natural and purchased of market and water. The data were analyzed statistically in CRD following the method (Steel and Torrie 1980).

\section{Result and Discussion}

The productive potentiality of rabbit under intensive rearing system in farmer's condition is shown in Table 1 . Adult body weight of rabbit was found significantly different $(\mathrm{P}<0.05)$ and concentrate feed also difference significantly $(\mathrm{P}<0.01)$ which was supported with findings of Ranjhan (1980). He observed that growing rabbits can be maintained satisfactorily on diets consisting of $100-200 \mathrm{~g}$ green roughage and 40-50g concentrate mixtures preferably in the form of pellet for optimum production. Live weight gain did not differ significantly $(\mathrm{P}>0.05)$ among the farmers. Feed cost for rabbit rearing at different farmers level was highly significance $(\mathrm{P}<0.01)$. The highest feed cost was recorded in $\mathrm{F}_{4}(1222 \mathrm{Tk})$ followed by the farmers of $\mathrm{F}_{5}(967 \mathrm{Tk}), \mathrm{F}_{1}(903 \mathrm{Tk}), \mathrm{F}_{3}(772 \mathrm{Tk})$ and $\mathrm{F}_{2}(732 \mathrm{Tk})$. In rural condition, farmers supply the green grass around their homestead but in urban area, farmers spent some money for green grass collection. Selected farmer's were generally provide green grass to rabbit as seasonal vegetables (Cabbage, data, collmi, pat, brenjal, immature banana tree, carrot, sweet potato, durba, lau, Jackfruit-motha, haycha grass) and napier grass. This observation fully support (Cheeke, 1986a; Cheeke et al.1985; Deshmukh and Pathak,1995). Huque et al, (2000) observed that a landless and/or marginal farmer can earn about Tk. 2300/- per month by rearing 10 rabbit and they also reported that different types of rabbit production system are being observed in different areas of Bangladesh such as; scavenging system, semi- scavenging system and intensive system.

They reported that rabbits are herbivores and can be successfully raised on diets that are low in grains and high in roughages. Monthly consumption of rabbit meat per family of $4.5 \mathrm{~kg}, 3 \mathrm{~kg}, 2.4$ 
$\mathrm{kg}, 6.0 \mathrm{~kg}$, in $\mathrm{F}_{1}, \mathrm{~F}_{2}, \mathrm{~F}_{3}$, and $\mathrm{F}_{5}$, respectively. This indicates that rabbit meat and rabbit farming are becoming popular enterprise in different regions of Bangladesh. This result almost similar with the findings of Roy et al. (2002).

Age of sexual maturity, age of first kidding, percentage of does kidded, gestation period, litter size, weaning period, breeding ratio were not differ significantly $(\mathrm{P}>0.05)$ among the locations. Birth weight of kid was almost similar in $\mathrm{F}_{1}, \mathrm{~F}_{2}, \mathrm{~F}_{3}, \mathrm{~F}_{4}$ and $\mathrm{F}_{5}$ but little less in $\mathrm{F}_{4}$. Birth weight of kid was 50.24g, 54.77g, 52.16g, 45.26g and 54.33g in $\mathrm{F}_{1}, \mathrm{~F}_{2}, \mathrm{~F}_{3}, \mathrm{~F}_{4}$ and $\mathrm{F}_{5}$, respectively. Lebes (1983) and Yono et al. (1986) reported heavier kid weight as a result of smaller litter size that support of current result. Kid mortality ( $0-10$ days) was differ significantly $(\mathrm{P}<0.01)$ among the locations and the values were recorded in $\mathrm{F}_{1}(8.47 \%), \mathrm{F}_{2}(11.11 \%), \mathrm{F}_{3}(12.00 \%), \mathrm{F}_{4}(8.82 \%)$ and $\mathrm{F}_{5}$ (13.11\%). Chen et al.(1978) indicated higher mortality among young rabbits older than 8 weeks, which supports current result.

During the experiment, disease incidence of rabbit were recorded bloat and diarrhoea in $\mathrm{F}_{1}$, skin disease in $F_{2}$, salmonellosis in $F_{3}$, diarrhoea in $F_{4}$ and skin disease and salmonellosis in $F_{5}$. One distinct attribute of epidemic diseases when a high standard of hygiene and careful management is practiced. In this study, it was observed that most of the farmer's marketed their rabbit for local consumption and supply to other farmer for rabbit farming, whereas, $\mathrm{F}_{4}$ farmer's marketed their rabbit in Katabone market (Dhaka). Farmer earned some money by selling their rabbit which was Tk10200, Tk7600, Tk8400, Tk12400, and Tk7200/batch and the total profit around 49,564Tk, 39,316Tk, 38,536Tk, 62,336Tk and 35,688 Tk per year by rearing 20 rabbits for 7 batch's per year in $\mathrm{F}_{1}, \mathrm{~F}_{2}, \mathrm{~F}_{3}, \mathrm{~F}_{4}$ and $\mathrm{F}_{5}$, respectively.

Table 1: Productive and reproductive performance and cost effectiveness of rabbit in farmers' condition

\begin{tabular}{|c|c|c|c|c|c|c|}
\hline \multirow{2}{*}{$\begin{array}{lll}\begin{array}{l}\text { Productive } \\
\text { parameters }\end{array} & \& & \text { Reproductive } \\
\end{array}$} & \multicolumn{5}{|c|}{ Different Farmer } & \multirow{2}{*}{$\begin{array}{l}\text { Level of } \\
\text { sig. }\end{array}$} \\
\hline & $\mathbf{F}_{1}$ & $\mathbf{F}_{2}$ & $\mathbf{F}_{3}$ & $\mathbf{F}_{4}$ & $\mathbf{F}_{5}$ & \\
\hline \multicolumn{7}{|l|}{ Adult body weight (gm): } \\
\hline Female & 1672 & 1604 & 1650 & 1750 & 1638 & $.001 *$ \\
\hline Male & 1744 & 1700 & 1697 & 1767 & 1697 & $.001 *$ \\
\hline Daily live weight gain(gm) & 3.20 & 3.01 & 2.00 & 3.02 & 2.07 & $.271^{\mathrm{NS}}$ \\
\hline \multicolumn{7}{|l|}{ Feed intake (gm/day): } \\
\hline Concentrate & 50.12 & 40.65 & 42.84 & 51.22 & 43.08 & $.000 * *$ \\
\hline Feed cost/month (Tk) & 903 & 732 & 772 & 1122 & 976 & - \\
\hline Meat consumption/month & 4.5 & 3.0 & 2.4 & - & 5.0 & - \\
\hline Age at sexual maturity (day) & 162 & 164 & 164 & 161 & 166 & $.007^{\mathrm{NS}}$ \\
\hline Age of first kidding (day) & 191 & 194 & 194 & 191 & 196 & $.428^{\mathrm{NS}}$ \\
\hline Percent of does kidded & 87.5 & 81.25 & 81.25 & 93.75 & 87.50 & - \\
\hline Gestation period (day) & 29.20 & 30.10 & 30.13 & 30.73 & 29.60 & $.210^{\mathrm{NS}}$ \\
\hline Litter size (number) & 4.22 & 3.45 & 3.80 & 4.50 & 3.20 & $.235^{\mathrm{NS}}$ \\
\hline Birth wt of offspring (gm) & 50.24 & 54.77 & 52.16 & 45.26 & 54.33 & $.000 * *$ \\
\hline Kid mortality (1-10 days) & 8.57 & 11.11 & 12.00 & 8.82 & 13.11 & $.000 * *$ \\
\hline Weaning weight (gm) & 380 & 376 & 399 & 413 & 410 & $.000 * *$ \\
\hline Weaning period (day) & 30 & 30 & 30 & 30 & 30 & - \\
\hline Breeding ratio & $4: 1$ & $4: 1$ & $4: 1$ & $4: 1$ & $4: 1$ & - \\
\hline Disease pattern & $\begin{array}{l}\text { Bloat , } \\
\text { diarrhea }\end{array}$ & $\begin{array}{l}\text { Skin } \\
\text { disease }\end{array}$ & $\begin{array}{l}\text { Salmonello } \\
\text { sis }\end{array}$ & Diarrhea & $\begin{array}{l}\text { Salmonel } \\
\text { losis }\end{array}$ & - \\
\hline Marketing of rabbit & $\begin{array}{l}\text { Local } \\
\text { consumptio }\end{array}$ & $\begin{array}{l}\text { For } \\
\text { farming }\end{array}$ & $\begin{array}{l}\text { For } \\
\text { farming }\end{array}$ & Dhaka & $\begin{array}{l}\text { Local } \\
\text { consumpt }\end{array}$ & - \\
\hline & $\begin{array}{l}\mathrm{n}+\text { for } \\
\text { farming }\end{array}$ & & & & ion & \\
\hline
\end{tabular}




\begin{tabular}{llllll|l} 
Economic return (family/bath(Tk) & $10,200 /-$ & $7600 /-$ & $8400 /-$ & $12400 /-$ & $7200 /-$ & - \\
Profit/year (Tk) & $49564 /-$ & $39316 /-$ & $38536 /-$ & $62336 /-$ & $35688 /-$ & - \\
\hline
\end{tabular}

$*=\mathrm{P}<0.05 ; * *=(\mathrm{P}<0.01)$ and $\mathrm{NS}=$ Non-significant

\section{Conclusion}

From the present findings, it may be concluded that the performance of rabbit under intensive management in rural condition was good. Location had a significant effect on feed cost of rabbit rearing. Therefore, rabbit production could be not only an important micro-livestock component to produce for meeting up extra demand of protein of the country but also an important tool for income generation and poverty reduction in the rural farmers.

\section{References}

Ali, S.M.K and Sukanta,1993. "Rabbit" Institute of Nutrition and Food science, university of Dhaka.

Cheeke, P. R. 1986a. Nutrition and feeding of rabbits (2nd ed).In: Livestock Feeds and Feeding (Ed.D.C.Church). Prentice-Hall, A Division of Simon and Schuster Inc., Englewood Cliffs, New Jersey 07632, USA, PP: 460-473.

Cheeke, P. R. 1986b. Potentials of rabbit production in tropical and subtropical agricultural systems. J. Anim. Sci., 63: 1581-1586.

Cheeke, P.R.,Sanchez, W.K. and Patton, N. M. 1985. Protein requirements for optimal growth and reproduction for rabbits. Nutr. Abst. Rev., 56: 331

Chen, C.P., Rao, D.R.,Sunki, G.R. and Johnson, W.M.1978. Effect of weaning and slaughter ages upon rabbit meat production: i. live weight, feed efficiency and mortality. J. Anim. Sci., 46(3): 573-577.

Deshmukh, S. V. and Pathak, N. M. 1995. Effect of nutrition and age on dry matter intake and nutrientutilization from compounded feed in rabbits. Ind. J. Anim. Nutr., 12: 31-34.

Hasanat, M.S., Hossain M.E., Mostari, M.P. and Hossain, M.A. 2006. Effect of concentrate supplementation on growth and reproductive performance of rabbit under rural condition. Bangl. J. Vet. Med., 4 (2): 129-132.

Handa, M.C., Sapra, K.L. and Shingai, B.K. 1995. Rabbits for meat production. Asian Livest., 20: 99-100.

Huque. Q. M. E. and Sarker, N.R. 2000. Potentiality of rabbit production: Bangladesh perspective. Unpublished report.

Huque, K. S. (2009). Livestock for food security-ways for achieving goal, the paper was presented in the $7^{\text {th }}$ annual scientific conference of Chittagong Veterinary and Anima Sciences University, Khulsi, Chittagong-4202.

Jones, N.D.1990. The developing market for farm-bred meat rabbits in Britain.

Lebas, F. (1983). Small scale rabbit production. Feeding and management system. World Anim. Rev., PP: 46.

MIDAS, 1992. Prospects of commercial rabbit raising in Bangladesh a survey report. Micro Industries Development Assistance Society. National Academy Press, Washington, D.C.

Roy, J., Sultana, N., Khondoker1, Z., Reza1, A. and Hossain, S. M. J. 2002. Effect of Different Sources of Protein on Growth and Reproductive Performances of Rabbits. Pakistan Journal of Nutrition. 1 (6): 279-281.

Ranjhan, 1980. Animal nutrition in tropics. Vkas Publishing house Pvt. Ltd. Sahibabad, Ghaziabad, P:335.

Steel, R. G. D. and. Torrie, J. H. 1980. Principle and Procedures of statistics. (2nd Ed.). McGraw- Hill Book Co. Inc. USA. 
Sandford, J.C. 1986. The domestic Rabbit. $4^{\text {th }}$ edition, Collins, 8 Grafton street. London, WIX 3LA.

Yono, C., Raharj, C., Cheeke, P.R. and Patton N.M. 1986. Growth and reproductive performance of rabbits on a moderately low crude protein diet with or without methionine or urea supplementation. J. Anim. Sci., 63: 795-803. 